\title{
DNA methylation profile in diffuse type gastric cancer: evidence for hypermethylation of the BRCA1 promoter region in early-onset gastric carcinogenesis
}

\author{
CAROLINA BERNAL ${ }^{1}$, MACARENA VARGAS ${ }^{1}$, FRANCISCO OSSANDÓN ${ }^{1}$, \\ EUDOCIA SANTIBÁÑEZ ${ }^{1}$, JULIO URRUTIA ${ }^{1}$, VÍCTOR LUENGO ${ }^{1}$, \\ LUIS F. ZAVALA ${ }^{1}$, CLAUDIA BACKHOUSE ${ }^{3}$, MARIANA PALMA $^{3}$, \\ JORGE ARGANDOÑA ${ }^{3}$, FRANCISCO AGUAYO ${ }^{2}$, and ALEJANDRO CORVALÁN ${ }^{1,2}$
}

\begin{abstract}
${ }^{1}$ Departmento Anatomía Patológica y ${ }^{2}$ Laboratorio Patología Molecular y Epidemiología, Centro Investigaciones Médicas, Pontificia Universidad Católica de Chile e ${ }^{3}$ Instituto Chileno Japonés de Enfermedades Digestivas, Hospital Clínico San Borja Arriarán, Santiago Chile.
\end{abstract}

\section{JOURNAL CATEGORY: Tumor genetics}

NOVELTY AND IMPACT: We identified that hypermethylation of BRCA1 is associated with young age, suggesting a role in early-onset gastric carcinoma. The low frequency of hypermethylation of the p73 gene in normal adjacent mucosa suggests that it might play a role in the early stages of diffuse type gastric carcinoma.

\begin{abstract}
Diffuse type gastric carcinoma is the most aggressive type of gastric cancer. This type of tumor is not preceded by precancerous changes and is associated with early-onset and hereditary syndromes. To test the hypothesis that DNA methylation profile would be useful for molecular classification of the diffuse type gastric carcinoma, DNA methylation patterns of the CpG Island of 17 genes were studied in 104 cases and 47 normal adjacent gastric mucosa by Methylation-specific PCR, Immunohistochemistry and Hierarchical clustering analysis. The most frequent methylated genes were FHIT, E-cadherin, BRCA1 and APC $(>50 \%)$, followed by p14, p16, p15, p73, MGMT and SEMA3B (20-49\%). Hierarchical clustering analysis reveals four groups with different clinical features. The first was characterized by hypermethylation of BRCA 1 and younger age ( $<45$ years old), and the second by hypermethylation of p14 and p16 genes, male predominance and Epstein-Barr virus infection. The third group was characterized by hypermethylation of FHIT and antrum located tumors and the fourth was not associated with any clinical variables. In normal adjacent mucosa only the p73 gene was significantly less methylated in comparison to tumor mucosa. DNA methylation identified subgroups of diffuse type gastric cancer. Hypermethylation of BRCA1 associated with young age suggests a role in early-onset gastric carcinoma.
\end{abstract}

Key terms: gastric cancer, diffuse type, early-onset, BRCA-1

\section{INTRODUCTION}

Gastric cancer is the fourth most common cancer and the second leading cause of cancerrelated death worldwide (Pisani et al., 2002). Although its incidence and mortality have fallen dramatically, gastric cancer remains a worldwide public health problem (Pisani et al., 2002; Rastogi et al., 2004). According to
Lauren's classification, there are two major histological types of gastric cancer, intestinal and diffuse (Lauren 1965). The diffuse type is the most aggressive form of gastric cancer and the mortality rate is increasing in spite of the decline of the intestinal type (Henson et al., 2004; Crew and Neugut 2006). In addition, the diffuse type is not preceded by sequential stages of precancerous changes, and tends to

Corresponding Author: Dr. Alejandro Corvalan, Laboratorio Patología Molecular y Epidemiología, Centro Investigaciones Médicas, Pontificia Universidad Católica de Chile, Marcoleta 391 Santiago 8330074 Chile, Phone: 56(2) 3548289, E-mail: corvalan@med.puc.cl 
arise “de novo" (Vauhkonen et al., 2006). Furthermore, early-onset gastric cancer and hereditary diffuse gastric cancer (HDGC) are both associated with diffuse type histology (Dunbier and Guilford 2001; Milne et al., 2007).

Particular alterations at the genetic and epigenetic levels in oncogenes and tumorsuppressor genes have been associated with the multistage process of gastric cancer (Tahara 2004; Yasui et al., 2005). In the diffuse type, the best characterized genetic alteration is the loss of heterozygosity $(\mathrm{LOH})$ of chromosome 17p and mutations of p53 and E-cadherin genes (Tamura 2006). In addition, amplification of K-sam and c-met, $\mathrm{LOH}$ at $1 \mathrm{p}$ and reduced p27 and nm23 expression have been associated with advanced stage disease and low survival rates (Yasui et al., 2005; Vauhkonen et al., 2006). In spite of these findings, no consistent gene alterations have been detected in diffuse type gastric cancer.

The identification and characterization of genes selectively hypermethylated in cancer may improve our understanding of gastric carcinoma (Esteller 2003). Several reports have shown frequent hypermethylation of tumor suppressor genes in the intestinal type of gastric cancer (Tamura 2006; Vauhkonen et al., 2006). However, besides hypermetylation of the promoter region of E-cadherin gene (Graziano et al., 2004), and more recently, PGP9.5 (Yamashita et al., 2006), no consistent information of the role of epigenetics in the diffuse type is currently available. In this study we used a candidate gene approach of 17 genes, covering all cellular pathways, to test the hypothesis that a hypermethylation profile would be useful for molecular classification of diffuse type gastric cancer. We also assessed the role of specific genes as molecular markers for the "de novo" precancerous changes in normal adjacent mucosa of paired tumor samples.

\section{MATERIALS AND METHODS}

\section{Clinical Samples}

We studied 104 formalin-fixed paraffinembedded archival specimens of diffuse type gastric cancer. All cases were selected using the histological criteria according to the Lauren's classification (Lauren 1965). In 47 of these cases, normal gastric mucosa adjacent to the tumor was also available. Clinical characteristics of these cases are shown in Table 1. In this series, 66 (63.5\%) cases were males with an age average of 58 years old and $17(16.3 \%)$ patients were under 45 years of age. Forty-three (41.3\%) tumors were located in cardia and 27 (26\%) in the antrum. In 3 cases $(2.9 \%)$ the location was not consigned. Fourteen $(13.5 \%)$ cases were at early stage. Seventy-one $(68.3 \%)$ of these cases were lymph node positive and 37 $(35.6 \%)$ had signet-ring cell features. In this series, $30(28.8 \%)$ cases were positive for EBV infection and had been reported previously (Corvalan et al., 2001). The date of the last follow-up and status (alive or dead) was available in 100 cases. The Institutional Review Boards of the Pontificia Universidad Católica de Chile and Hospital Clínico San Borja Arriarán, Santiago Chile approved this study.

\section{DNA extraction}

Five $15 \mu \mathrm{m}$ paraffin sections of representative areas of diffuse type gastric carcinoma ( $>70 \%$ tumor cells) were cut and placed into a $0.5 \mathrm{~mL}$ tube for DNA extraction. DNA extraction was performed in a $100 \mu \mathrm{L}$ extraction solution (1 M Tris $\mathrm{pH}$ 8.0, $50 \mathrm{mM}$ EDTA, $0.5 \%$ and Tween 20) with $1 \mathrm{mg} / \mathrm{mL}$ Proteinase K (Sigma) for $12 \mathrm{hrs}$ at $55^{\circ} \mathrm{C}$. Proteinase $\mathrm{K}$ was inactivated by boiling at $100^{\circ} \mathrm{C}$ for 10 minutes and DNA was purified by phenolchloroform extraction and ethanol precipitation according to standard protocols. DNA concentration was determined by spectroscopy using 1 OD260 for $50 \mu \mathrm{g} / \mathrm{ml}$.

\section{DNA Methylation Assays}

DNA was treated with sodium bisulphite as described previously (Riquelme et al., 2007). Briefly, $1 \mu \mathrm{g}$ of genomic DNA was denatured by incubation with $0.2 \mathrm{M} \mathrm{NaOH}$ for $10 \mathrm{~min}$ at $37^{\circ} \mathrm{C}$. Aliquots of $10 \mathrm{mM}$ hydroquinone (30 ul; Sigma Chemical Co., St. Louis, MO) and $3 \mathrm{M}$ sodium bisulphite 
(pH 5.0; 520 ul; Sigma Chemical Co.) were added, and the solution was incubated at 50 ${ }^{\circ} \mathrm{C}$ for $16 \mathrm{~h}$. Treated DNA was purified by use of the Wizard DNA Purification System (Promega Corp., Madison, WI), desulfonated with $0.3 \mathrm{M} \mathrm{NaOH}$, precipitated with ethanol, and resuspended in water. Modified DNA was stored at $-80^{\circ} \mathrm{C}$ until used. The methylation status of 17 genes (APC, BRCA1, DAPK, ER, E-cadherin, FHIT, GSTP, hMLH1, MGMT, p14, p15, p16, p73, RARb, SEMA3B, SOCS, TIMP3) was determined by methylation-specific polymerase chain reaction (MS-PCR) (Herman and Baylin 2003) and details on primer sequences and PCR conditions are available upon request. These genes were chosen because they are known to be tumor suppressor genes, methylation at these $\mathrm{CpG}$ sites is associated with gene silencing, they cover essential alterations in cell physiology that collectively dictate malignant growth and they had previously been described as undergoing hypermethylation in other tumor types (Hanahan and Weinberg 2000; Virmani et al., 2000; Chan et al., 2002; Li et al., 2002; Oka et al., 2002; Sato et al., 2002; Kuroki et al., 2003; Miyamoto et al., 2003; Wild et al., 2003; Sarbia et al., 2004; Takahashi et al., 2004; Xu et al., 2004; Kim et al., 2005; Kim et al., 2005; Liu et al., 2005; Takahashi et al., 2005; Kawaguchi et al., 2006; Mori et al., 2006; Tamura 2006; Riquelme et al., 2007). Gene names, gene location and function for each gene selected in this study is summarized in Table 2. Only cases with positive unmethylated bands were considered informative for methylation status in this study. All reactions were done in triplicate. In vitro methylated Sss 1 methyltransferase (New England Biolabs) and bisulfite-modified DNA from the MKN45 cell line were used as a positive control. Samples without DNA template (water only) were included as negative control for each set of PCR reaction.

TABLE 1

Clinical associations of clusters of gene methylation in diffuse type gastric cancer

\begin{tabular}{|c|c|c|c|c|c|c|c|c|c|c|c|c|}
\hline \multirow[t]{2}{*}{$\begin{array}{l}\text { Clinical } \\
\text { variables }\end{array}$} & & \multicolumn{2}{|c|}{$\begin{array}{c}\text { BRCA1 } \\
\text { cluster }\end{array}$} & \multicolumn{2}{|c|}{$\begin{array}{c}\mathrm{p} 14 / \mathrm{p} 16 \\
\text { cluster }\end{array}$} & \multicolumn{2}{|c|}{$\begin{array}{l}\text { FHIT } \\
\text { cluster }\end{array}$} & \multicolumn{2}{|c|}{$\begin{array}{c}\text { low MI } \\
\text { cluster }\end{array}$} & \multirow[b]{2}{*}{$\mathrm{p}$} & \multirow[b]{2}{*}{ Total } & \multirow[b]{2}{*}{$\%$} \\
\hline & & $\mathrm{N}$ & $\%$ & $\mathrm{~N}$ & $\%$ & $\mathrm{~N}$ & $\%$ & $\mathrm{~N}$ & $\%$ & & & \\
\hline Gender & $\begin{array}{l}\text { female } \\
\text { male }\end{array}$ & $\begin{array}{l}12 \\
11\end{array}$ & $\begin{array}{l}52.2 \\
47.8\end{array}$ & $\begin{array}{r}7 \\
25\end{array}$ & $\begin{array}{l}21.9 \\
78.1\end{array}$ & $\begin{array}{l}12 \\
16\end{array}$ & $\begin{array}{l}42.9 \\
57.1\end{array}$ & $\begin{array}{r}7 \\
14\end{array}$ & $\begin{array}{l}33.3 \\
66.7\end{array}$ & $.02^{\mathrm{a}}$ & $\begin{array}{l}38 \\
66\end{array}$ & $\begin{array}{l}36.5 \\
63.5\end{array}$ \\
\hline Age & $\begin{array}{l}<45 \text { у.о. } \\
>45 \text { у.о. }\end{array}$ & $\begin{array}{r}8 \\
15\end{array}$ & $\begin{array}{l}34.8 \\
65.2\end{array}$ & $\begin{array}{r}4 \\
28\end{array}$ & $\begin{array}{l}12.5 \\
87.5\end{array}$ & $\begin{array}{r}4 \\
24\end{array}$ & $\begin{array}{l}14.3 \\
85.7\end{array}$ & $\begin{array}{r}1 \\
20\end{array}$ & $\begin{array}{c}4.8 \\
95.2\end{array}$ & $.009^{\mathrm{b}}$ & $\begin{array}{l}17 \\
87\end{array}$ & $\begin{array}{l}16.3 \\
83.7\end{array}$ \\
\hline Follow-up & $\begin{array}{l}\text { alive } \\
\text { dead }\end{array}$ & $\begin{array}{l}10 \\
13\end{array}$ & $\begin{array}{l}43.5 \\
56.5\end{array}$ & $\begin{array}{l}15 \\
17\end{array}$ & $\begin{array}{l}46.9 \\
53.1\end{array}$ & $\begin{array}{l}12 \\
16\end{array}$ & $\begin{array}{l}42.9 \\
57.1\end{array}$ & $\begin{array}{l}9 \\
8\end{array}$ & $\begin{array}{l}52.9 \\
47.1\end{array}$ & & $\begin{array}{l}46 \\
54\end{array}$ & $\begin{array}{l}46.0 \\
54.0\end{array}$ \\
\hline Location & $\begin{array}{l}\text { cardia } \\
\text { middle } \\
\text { antrum }\end{array}$ & $\begin{array}{r}8 \\
10 \\
5\end{array}$ & $\begin{array}{l}34.8 \\
43.5 \\
21.7\end{array}$ & $\begin{array}{r}15 \\
10 \\
5\end{array}$ & $\begin{array}{l}50.0 \\
33.3 \\
16.7\end{array}$ & $\begin{array}{r}11 \\
4 \\
12\end{array}$ & $\begin{array}{l}40.7 \\
14.8 \\
44.4\end{array}$ & $\begin{array}{l}9 \\
7 \\
5\end{array}$ & $\begin{array}{l}42.9 \\
33.3 \\
23.8\end{array}$ & $.02^{\mathrm{c}}$ & $\begin{array}{l}43 \\
31 \\
27\end{array}$ & $\begin{array}{l}41.3 \\
29.8 \\
26.0\end{array}$ \\
\hline Tumor size & $\begin{array}{l}<5 \mathrm{~cm} \\
>5 \mathrm{~cm}\end{array}$ & $\begin{array}{r}7 \\
16\end{array}$ & $\begin{array}{l}30.4 \\
69.6\end{array}$ & $\begin{array}{r}6 \\
24\end{array}$ & $\begin{array}{l}20.0 \\
80.0\end{array}$ & $\begin{array}{r}9 \\
17\end{array}$ & $\begin{array}{l}34.6 \\
65.4\end{array}$ & $\begin{array}{r}7 \\
13\end{array}$ & $\begin{array}{l}35.0 \\
65.0\end{array}$ & NS & $\begin{array}{l}29 \\
70\end{array}$ & $\begin{array}{l}29.3 \\
70.7\end{array}$ \\
\hline Stage & $\begin{array}{l}\text { early } \\
\text { advanced }\end{array}$ & $\begin{array}{r}4 \\
19\end{array}$ & $\begin{array}{l}17.4 \\
82.6\end{array}$ & $\begin{array}{r}5 \\
25\end{array}$ & $\begin{array}{l}16.7 \\
83.3\end{array}$ & $\begin{array}{r}2 \\
26\end{array}$ & $\begin{array}{c}7.1 \\
92.9\end{array}$ & $\begin{array}{r}3 \\
18\end{array}$ & $\begin{array}{l}14.3 \\
85.7\end{array}$ & NS & $\begin{array}{l}14 \\
88\end{array}$ & $\begin{array}{l}13.5 \\
84.6\end{array}$ \\
\hline Signet-ring & $\begin{array}{l}\text { negative } \\
\text { positive }\end{array}$ & $\begin{array}{r}16 \\
6\end{array}$ & $\begin{array}{l}72.7 \\
27.3\end{array}$ & $\begin{array}{l}19 \\
12\end{array}$ & $\begin{array}{l}61.3 \\
38.7\end{array}$ & $\begin{array}{r}18 \\
9\end{array}$ & $\begin{array}{l}66.7 \\
33.3\end{array}$ & $\begin{array}{l}11 \\
10\end{array}$ & $\begin{array}{l}52.4 \\
47.6\end{array}$ & NS & $\begin{array}{l}64 \\
37\end{array}$ & $\begin{array}{l}61.5 \\
35.6\end{array}$ \\
\hline Lymph nodes & $\begin{array}{l}\text { negative } \\
\text { positive }\end{array}$ & $\begin{array}{r}4 \\
18\end{array}$ & $\begin{array}{l}18.2 \\
81.8\end{array}$ & $\begin{array}{l}10 \\
20\end{array}$ & $\begin{array}{l}33.3 \\
66.7\end{array}$ & $\begin{array}{r}8 \\
19\end{array}$ & $\begin{array}{l}29.6 \\
70.4\end{array}$ & $\begin{array}{r}7 \\
14\end{array}$ & $\begin{array}{l}33.3 \\
66.7\end{array}$ & NS & $\begin{array}{l}29 \\
71\end{array}$ & $\begin{array}{l}27.9 \\
68.3\end{array}$ \\
\hline EBV & $\begin{array}{l}\text { negative } \\
\text { positive }\end{array}$ & $\begin{array}{r}17 \\
6\end{array}$ & $\begin{array}{l}73.9 \\
26.1\end{array}$ & $\begin{array}{l}16 \\
15\end{array}$ & $\begin{array}{l}51.6 \\
48.4\end{array}$ & $\begin{array}{r}19 \\
6\end{array}$ & $\begin{array}{l}76.0 \\
24.0\end{array}$ & $\begin{array}{r}15 \\
3\end{array}$ & $\begin{array}{l}83.3 \\
16.7\end{array}$ & $.008^{\mathrm{d}}$ & $\begin{array}{l}67 \\
30\end{array}$ & $\begin{array}{l}64.4 \\
28.8\end{array}$ \\
\hline
\end{tabular}

${ }^{a}$ p14/p16 cluster vs all others. ${ }^{b}$ BRCA1 cluster vs all others. ${ }^{c}$ FHIT cluster vs all others. ${ }^{d}$ p $14 / p 16$ cluster vs all others. 
TABLE 2

Summary data of genes tested for aberrant promoter hypermethylation in Diffuse-type gastric cancer

\begin{tabular}{|c|c|c|c|}
\hline $\begin{array}{l}\text { Gene } \\
\text { Abbreviation }\end{array}$ & $\begin{array}{l}\text { Gene } \\
\text { Name }\end{array}$ & Location & Function \\
\hline APC & Adenomatous polyposis coli gene & $5 \mathrm{q} 21$ & Signal transduction \\
\hline BRCA1 & Breast cancer 1 gene & $17 \mathrm{q} 2$ & DNA repair \\
\hline DAPK & Death-associated protein kinase & $9 q 34$ & Evasion of programmed cell death \\
\hline $\mathrm{CDH} 1$ & E-cadherin & $16 \mathrm{p}$ & cell adhesion \\
\hline ER & Estrogen Receptor & $6 \mathrm{q} 25.1$ & DNA binding, activation transcription \\
\hline FHIT & Fragile histidine triad & $3 \mathrm{p} 14.2$ & Evasion of programmed cell death \\
\hline GSTp1 & $\begin{array}{l}\text { Homologous to the MTG/ETO family } \\
\text { of transcription factors }\end{array}$ & $3 \mathrm{p} 21.3$ & Cell cycle regulation \\
\hline hMLH1 & $\begin{array}{l}\text { Human homologs of the MutL gene of } \\
\text { bacteria }\end{array}$ & $3 \mathrm{p} 21.3$ & DNA repair (Mismatch repair genes) \\
\hline MGMT & $\begin{array}{l}\text { O-6-methylguanine-DNA } \\
\text { methyltransferase }\end{array}$ & $10 \mathrm{q} 26$ & DNA repair \\
\hline p14 & Cyclin-dependent kinase inhibitor $2 \mathrm{~B}$ & $9 \mathrm{p} 21$ & Cell cycle regulation \\
\hline $\mathrm{p} 15$ & Cyclin-dependent kinase inhibitor $2 \mathrm{~B}$ & $9 \mathrm{p} 21$ & Cell cycle regulation \\
\hline $\mathrm{p} 16$ & Cyclin-dependent kinase inhibitor $2 \mathrm{~A}$ & $9 \mathrm{p} 21$ & Cell cycle regulation \\
\hline $\mathrm{p} 73$ & TP73 & $1 \mathrm{p} 36$ & Angiogenesis \\
\hline RAR-b & Retinoic acid receptor beta 2 gene & $3 \mathrm{p} 24$ & DNA binding, activation transcription \\
\hline SEMA3B & Semaphorin 3B & $3 p 21.3$ & Evasion of programmed cell death \\
\hline SOCS & $\begin{array}{l}\text { ankyrin repeat and SOCS } \\
\text { box-containing } 11\end{array}$ & $\mathrm{Xp} 22.31$ & Suppressor of cytokine signalling \\
\hline TIMP3 & Tissue inhibitor of metalloproteinase-3 & $22 \mathrm{q} 12$ & Tissue invasion and metastasis \\
\hline
\end{tabular}

\section{Protein expression assays}

To establish the association between $\mathrm{CpG}$ island hypermethylation and gene silencing we determined protein expression by immunohistochemistry assay on tissue microarray (TMA) slides. Tissue microarrays were performed using a Manual Tissue Arrayer II instrument (Beecher Instruments, Silver Spring, Maryland, USA). Archival tumor tissue blocks from 104 tumors were selected, cut and stained with hematoxylin and eosin for the best tumor area identification. After whole-section glass slide evaluation, tumor area was selected for placement into the TMA by a circling on the glass slide and identified in the corresponding paraffin block. Six hundred $\mu \mathrm{m}$ stylets in inner diameter were used to take three cylindrical core biopsies from each tumor tissue block (donor block), with subsequent arraying into a new recipient paraffin block. In this way, all 104 cases were held in the 3 recipient blocks. An adequate case was defined as a tumor occupying more than $10 \%$ of the core area. Immunohistochemistry was performed on 4- $\mu$ m-thick section TMA blocks. Sections were dewaxed in xylene, rehydrated through graded alcohol, and placed in an endogenous peroxide block for 15 minutes. Antigen retrieval was performed in a citrate buffer $(10 \%$ citrate buffer stock in distilled water, $\mathrm{pH}$ 6.0) and microwaved for 10 minutes. Non-reactive staining was blocked by $1 \%$ horse serum in Tris-buffered saline, pH6.0 for 3 minutes. After primary incubation, antibody binding was detected using two-stage visualization systems based on an enzyme-conjugated polymer backbone carrying secondary antibody 
molecules (EnVision ${ }^{\mathrm{TM}}$ Systems, Dako Cytomation). Protein expression of Ecadherin, p16 and p73 on TMA was determined in which cell membrane (Ecadherin) and nuclear (p16 and p73) staining from $10 \%$ or more tumor cells was considered positive for expression (Fig. 2).

\section{Data Analysis}

In order to identify clinically relevant groups based on to the DNA methylation pattern, we performed hierarchical clustering analysis in a similar fashion to cDNA expression microarrays in breast tumors and lymphomas (Alizadeh et al., 2000; van 't Veer et al., 2002) or more recently, DNA methylation signature in neuroblastoma (10 genes) or hepatocellular carcinoma (18 genes) (Alaminos et al., 2004; Nishida et al., 2007). TIGR MultiExperiment Viewer was applied to the DNA methylation dataset using unsupervised hierarchical clustering analysis with Pearson correlation and complete linkage to cluster the tumors. In addition, we analyzed this data using the Methylation index, defined as the number of methylated genes, divided by the total number of genes analyzed, as a way to compare the methylation status of each cluster. Clinical variables and follow-up data of cases from each particular cluster were compared using c2 tests. Survival analysis was performed using the KaplanMeier method and differences among groups were compared with the Log-rank testing and Cox regression models (Stata 8.0, Stata Corporation; College Station, TX). For all tests, probability values of $\mathrm{p}<0.05$ were regarded as statistically significant.

\section{RESULTS}

Frequency of the DNA methylation in diffuse type gastric cancer

As shown in Fig. 1A, the most frequent methylated genes ( $>50 \%$ cases) were FHIT, E-cadherin, BRCA1, APC. Genes with intermediate frequency of methylation (20-
49\%) were p14, p16, p15, p73, MGMT and SEMA3B. Genes with a low level of methylation $(<20 \%)$ were RARbeta, hMLH1, DAPK, ER, TIMP3, GSTP and SOCS. Representative examples are shown in Fig. 1B.

\section{Correlations between DNA methylation and loss of protein expression}

To establish the association between DNA methylation and gene silencing, we determined protein expression of three genes that were methylated in a relatively large number of cases (E-cadherin, p16 and p73). This analysis was performed in all 104 tested cases. For all three genes, the presence of $\mathrm{CpG}$ island methylation was associated with loss of protein expression. Conversely, in those cases harbouring an unmethylated $\mathrm{CpG}$ island, each gene was expressed. Representative examples are shown in Fig.2.

\section{DNA methylation patterns and clinical variables}

To explore the relationship among DNA methylation patterns and clinical variables, we performed unsupervised hierarchical clustering analysis. As shown in Fig. 3, clustering analysis revealed two different clusters, both further subdivided into two major branches. The most upper branch was characterized by hypermethylation of BRCA1 gene $(p=0.0006)$. The second branch was characterized by hypermethylation of p14 and p16 $(\mathrm{p}<0.0001)$. The upper branch of the second major cluster was characterized by hypermethylation of FHIT $(\mathrm{p}<0.0001)$ and the lower branch was not associated with hypermethylation of any specific gene. Accordingly, methylation index analysis revealed that this cluster was significantly less methylated in comparison to all other clusters $(\mathrm{p}<0.0001)$ (data not shown). Subsequently, clinical variables of cases from each cluster were compared and are shown in Table 1. The most upper branch (BRCA1 cluster) was associated with patients of younger age (age $<45$ y.o.) $(\mathrm{p}=0.009)$. The second branch $(\mathrm{p} 14 / \mathrm{p} 16$ cluster) was associated with male 
predominance $(p=0.002)$ and Epstein-Barr virus infection $(\mathrm{p}=0.008)$. The upper branch of the second major cluster (FHIT cluster) was associated with antrum as the predominant location $(\mathrm{p}=0.02)$. Finally, the lower branch of the second major group (low methylation index cluster) was not related to any specific clinical variables.

\section{Survival Analysis}

The impact in prognosis of clusters and individual genes was examined by survival analysis using Kaplan-Meier method, Logrank testing, and Cox regression models. The average follow-up period was 64 months (Standard deviation $=48$, range 1 146). Univariate analysis, using all four branches or individual genes, demonstrated that no clusters or single gene was significantly correlated with worse prognosis. Multivariate Cox regression analysis showed that only the lymph node metastasis was prognostic determinant $(\mathrm{HR}=3.06,95 \% \mathrm{CI}=1.07-8.7 ; \mathrm{p}=0.03)($ data not shown).

\section{A}

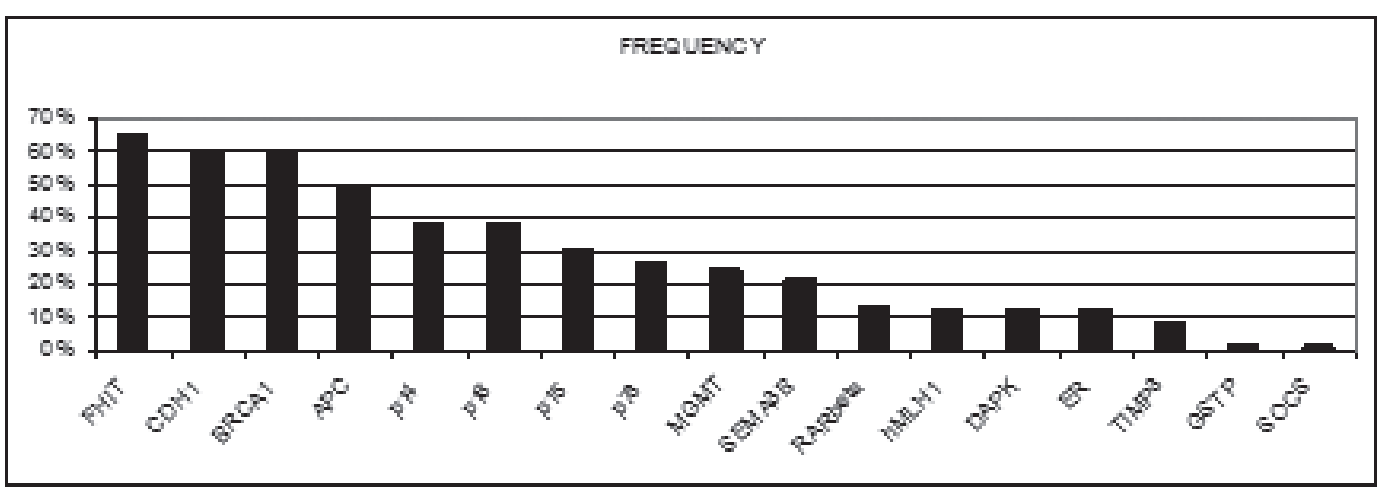

$\mathbf{B}$

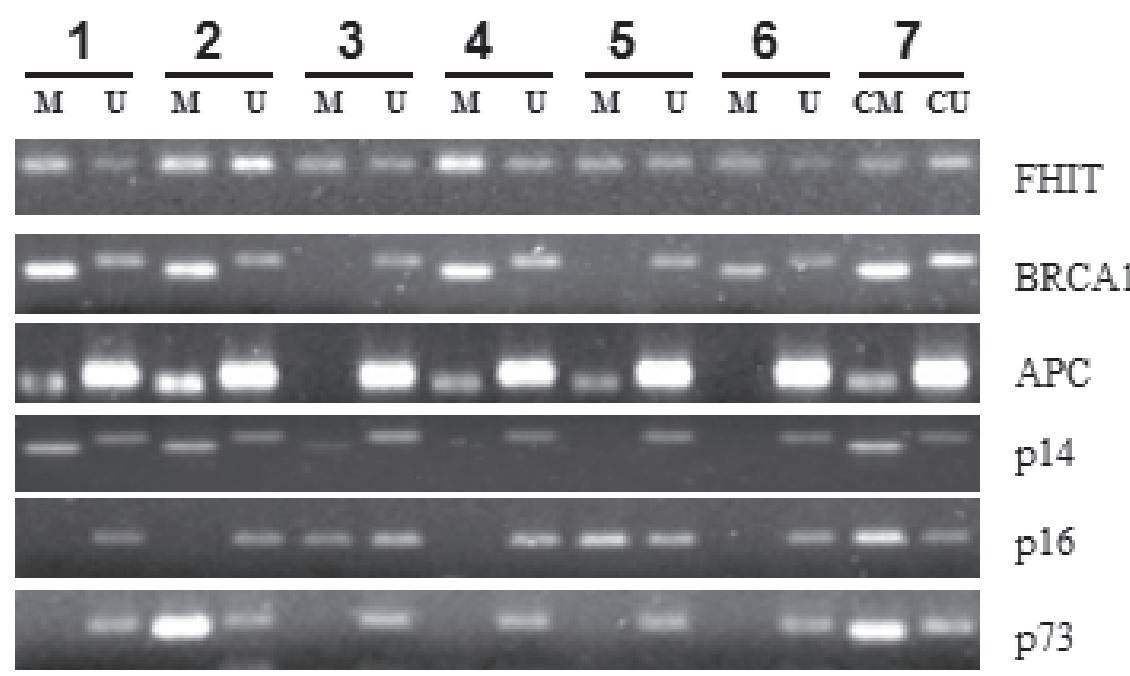

Fig. 1: Methylation-specific polymerase chain reaction (MS-PCR) analysis of 104 diffuse-type gastric carcinomas. (A) Histogram representing the percentage of tumors showing methylation for the 17 genes as indicated. B) Representative results. M PCR product with primers specific for methylated DNA, U PCR product with primers for unmethylated DNA; CM positive control for methylated DNA; CU positive control for unmethylated DNA. 


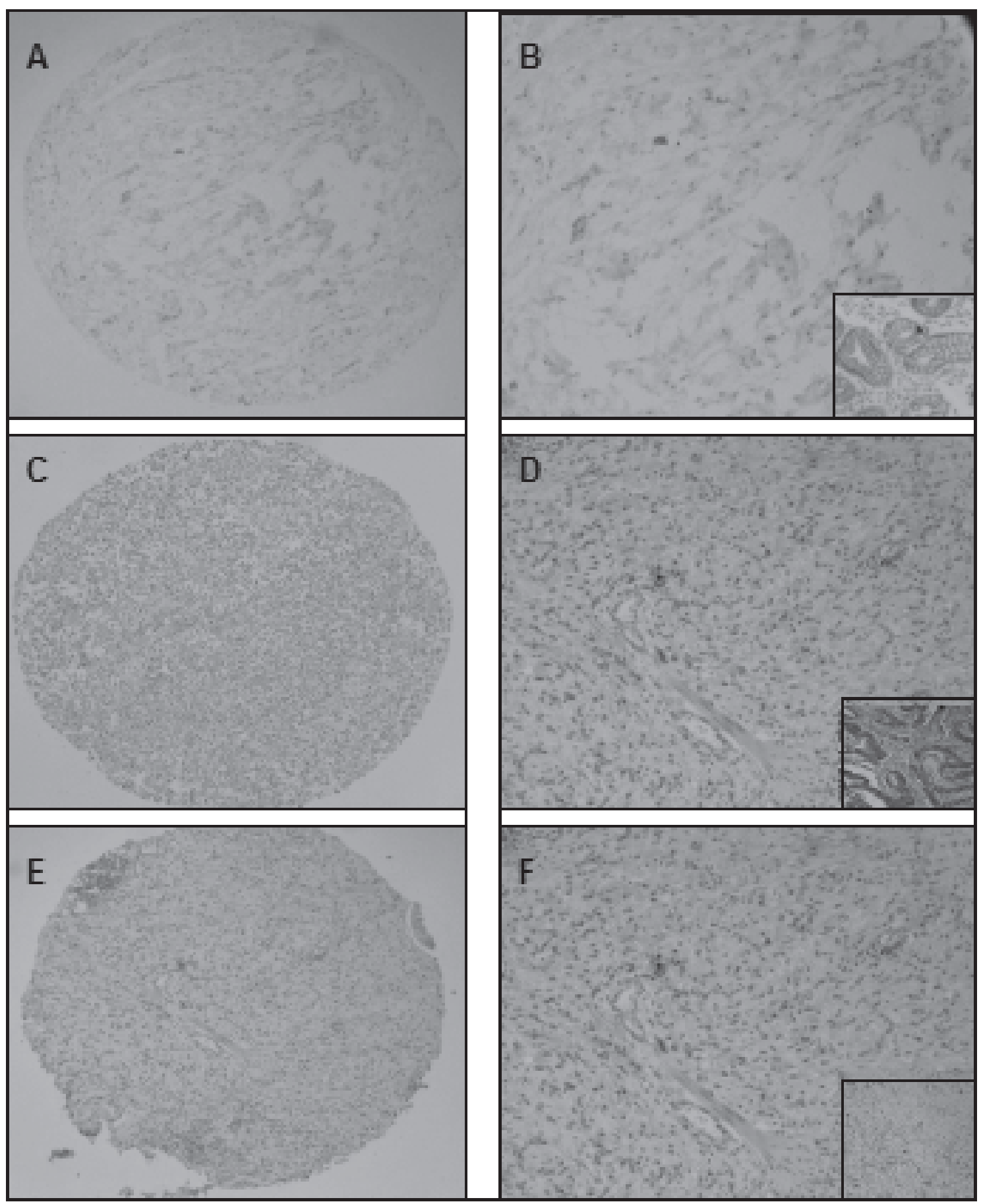

Fig. 2 Lack of protein expression at low (A, C and E) and high (B, D and F) magnification of Ecadherin (A-B), p16 (C-D) and p73 (E-F) on tissue microarray of diffuse-type gastric cancer. Positive controls for each antibody are shown in the corresponding inserts. 


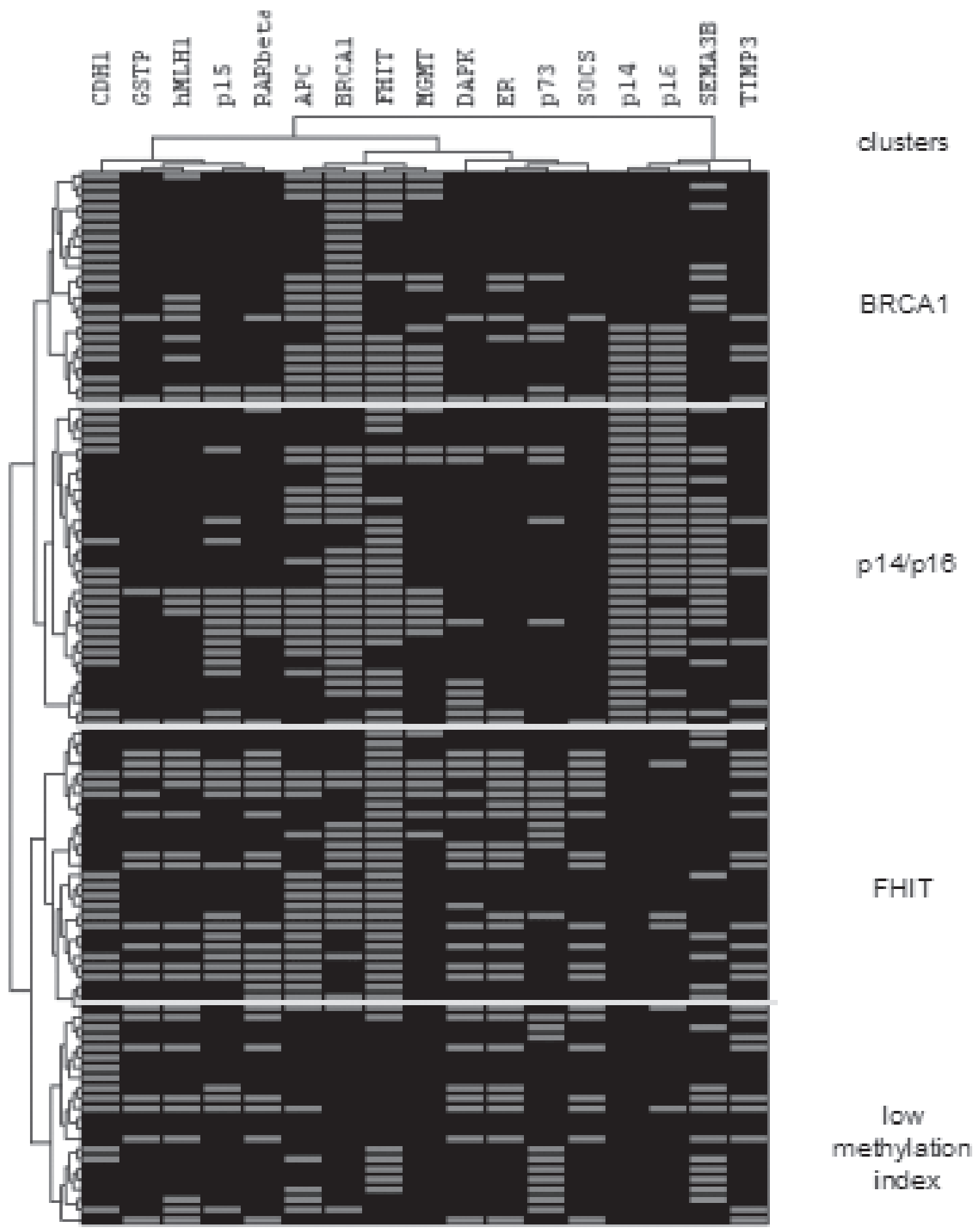

Fig. 3: Unsupervised Hierarchical Clustering analysis of 104 diffuse-type gastric cancer showing two different clusters, both further subdivided into two major groups. Each row represents a tumor and each column a single gene. Red indicates positive, black negative and gray not determined. 
DNA methylation patterns in normal adjacent mucosa from diffuse type gastric cancer

The frequency of DNA methylation patterns of the CpG Island of 8 genes was studied in a subgroup of 47 paired tumor and normal adjacent mucosa. The most representative genes of each cluster (BRCA1, p14/p16 and FHIT) and 4 non-cluster related genes (APC, MGMT, p15 and p73 genes) were included in this analysis. Case-informative incidence ranged from 8 to 39 samples. As shown in Fig 4A, only the p73 gene was significant less methylated in normal adjacent mucosa in comparison to tumor mucosa $(\mathrm{p}=0.006)$. Representative examples are shown in Fig. 4B.

\section{DISCUSSION}

In order to define the DNA methylation signature in diffuse type gastric carcinoma, the most aggressive and increasing form of gastric cancer, we used the candidate gene approach by searching the hypermethylation profile of $\mathrm{CpG}$ Island of 17 genes. To identify associations between genes and clinical variables, we performed hierarchical clustering analysis in a similar fashion to cDNA expression microarrays in breast tumors and lymphomas (Alizadeh et al., 2000; van 't Veer et al., 2002) or DNA methylation signature in Neuroblastoma (Alaminos et al., 2004) or Hepatocellular carcinoma (Nishida et al., 2007). Here, we found that DNA methylation is a frequent event in diffuse type gastric cancer and clustering analysis reveals different branches associated with hypermethylation of specific genes. Interestingly, these branches were associated with distinct clinical variables. For example, BRCA1 was frequently more methylated in a group of tumors associated with young age $(<45$ years old). Tumors at this age or less have been considered early-onset gastric cancer (Milne et al., 2007) and although they represent less than $10 \%$ of gastric carcinoma, they have unique clinicopathological features including diffuse type histology (Milne et al., 2007). Although early onset also has unique molecular features (lack of microsatellite instability, infrequent $\mathrm{LOH}$, low COX2 expression, infrequent loss of TFF1 expression, no loss of RUNX3, gains at chromosomes 17q, 19q and 20q) (Milne et al., 2007), DNA methylation has not been extensively explored in this type of gastric cancer. Only Kim et al (Kim et al., 2005) assayed the hypermethylation status in genes associated with the APC-beta-catenin axis and the mismatch repair system (hMLH1, TIMP3, THBS1, DAPK, GSTP1, APC, and MINT2) and found that hypermethylation is a frequent phenomenon in early-onset gastric carcinoma. However, no specific genes were hypermethylated. Thus, to our knowledge this is the first report that has identified hypermethylation of $\mathrm{CpG}$ island of the BRCA1 gene in association with early-onset gastric carcinoma. Interestingly, Varis et al (Varis et al., 2003) identified increases of DNA copy number at chromosome $17 \mathrm{q}$, the location of the BRCA1 gene, in $52 \%$ of 22 cases of earlyonset gastric cancer and Semba et al (Semba et al., 1998) described LOH on chromosome 17q12-21 with several neighbouring markers in this region, while no mutation was found in the BRCA1 gene. In addition, although associated with hereditary and not early-onset gastric cancer, studies exploring additional tumors on relatives of BRCA1 carriers identified gastric cancer as one of the most common sites for malignancies (Gallardo et al., 2006). Taken together, these findings suggest that alterations of the BRCA1 gene should be included as one of the molecular features of early-onset gastric carcinoma.

An association of hypermethylation of p14 and p16 and the presence of EpsteinBarr virus infection were characteristic of the lower cluster of the upper branch in the clustering analysis. This association has been described previously (Koriyama et al., 2004). However, our male gender association is contrary to previous studies for p16 methylation (Vauhkonen et al., 2006). Hypermethylation of FHIT has been associated with antrum as a predominant location. Interestingly, recent data showed that FHIT knock-out mice develop tumors 
in the forestomach and small intestines (Fujishita et al., 2004). These findings suggest that FHIT plays an important role in the integrity of gastrointestinal mucosal structures. Chang et al (Chang et al., 2002) described frequent $\mathrm{LOH}$ at the FHIT locus and loss of Fhit protein expression in a series of 7 signet-ring cell gastric cancer. Although these authors have proposed that alteration of the FHIT gene might be the hallmark of signet-ring cell gastric cancer, we did not confirm this.

The finding that seven out of 8 tested genes (with the only exception being the p73 gene) were hypermethylated in a similar frequency in normal adjacent mucosa in comparison to tumor mucosa, suggests the presence of an epigenetic field for cancerization (Ushijima 2007). Epigenetic field for cancerization has been

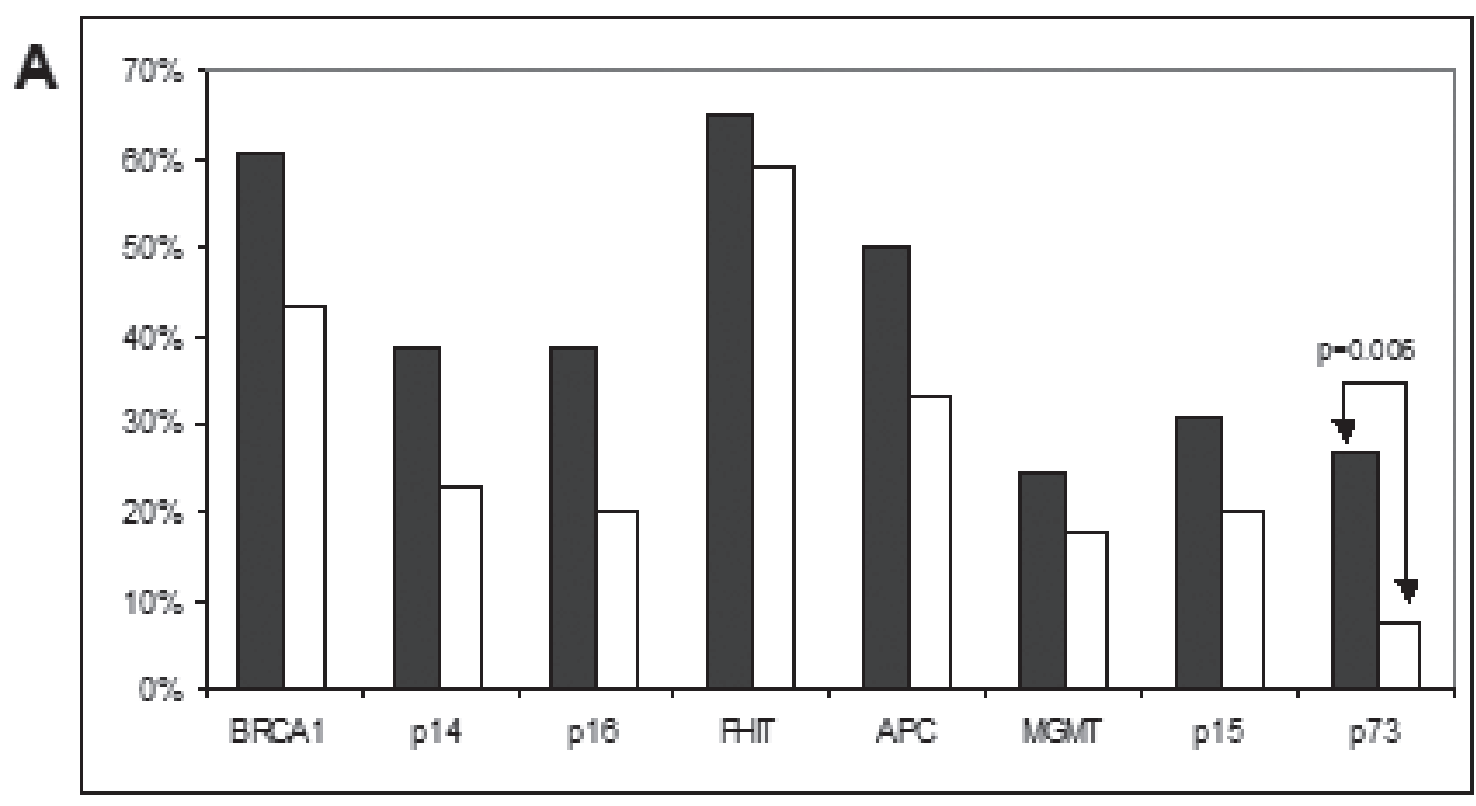

CASE 1

CASE 2

CASE 3

B

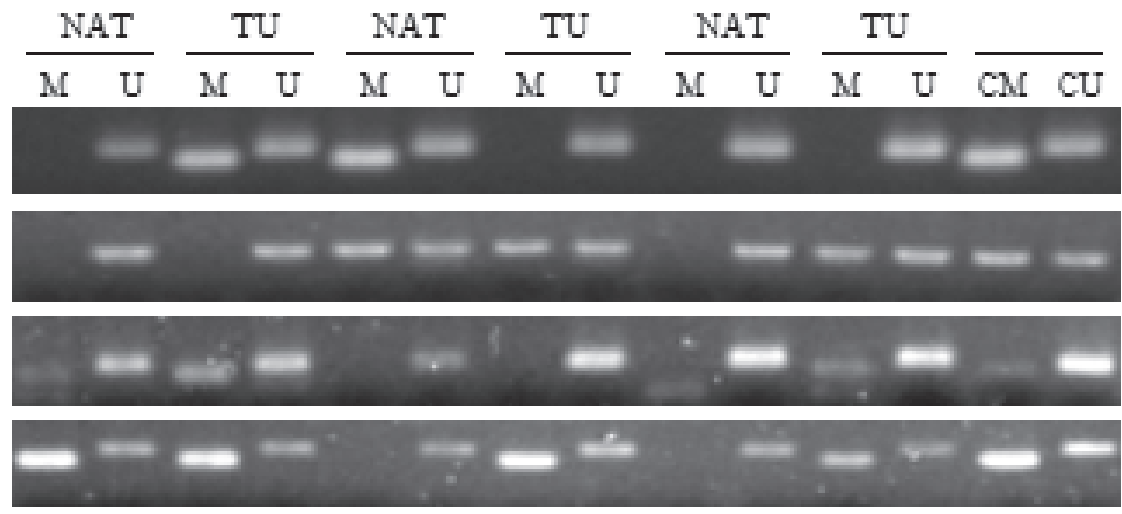

p14

p16

BRCA1

p73

Fig. 4: Methylation-specific polymerase chain reaction (MS-PCR) analysis of 47 paired tumor and non-tumor adjacent mucosa of diffuse-type gastric cancer. (A) Histogram representing the percentage of cases showing methylation for the most representative genes as indicated. Black indicates tumor mucosa and white indicates normal adjacent mucosa. B) Representative results. M PCR product with primers specific for methylated DNA, U PCR product with primers for unmethylated DNA; CM positive control for methylated DNA; CU positive control for unmethylated DNA. 
demonstrated for Barrett's esophagus, liver, lung and urothelial cancers (Eads et al., 2000; Wistuba et al., 2002). Since changes in DNA methylation status are specific for each tumor, it is likely that specific genes are methylated according to unique carcinogenic factors (Ushijima 2007). The p73 gene was the only one not hypermethylated in normal adjacent mucosa in comparison to tumor mucosa. Diffuse type gastric cancer does not have sequential stages of precancerous changes, as does intestinal-type gastric cancer, and consequently is considered to arise "de novo" (Vauhkonen et al., 2006). Thus, this finding suggests that hypermethylation of p73 might play an important role in the early stages of diffuse type gastric carcinoma. Extremely low levels of p73 expression has been observed in gastric cancer cell lines, although reports have shown that mutations of $\mathrm{p} 73$ are rare in primary human cancers (Pilozzi et al., 2003). These findings suggest that p73 could be a target of epigenetic regulation in gastric carcinogenesis.

In summary, we found that in DNA, methylation is a frequent event in diffuse type gastric cancer. Clustering analysis reveals specific association between genes and clinical variables, in particular BRCA1 to early-onset gastric carcinoma. The finding that the p73 gene was significantly less methylated in normal adjacent mucosa suggests that it may play a role in the early stages of diffuse type gastric carcinoma.

\section{ACKNOWLEDGMENTS}

Supported by FONDECYT Grant 1030130 and FONIS Grant SA06I20019 from Chilean government.

\section{REFERENCES}

ALAMINOS, M, V DAVALOS, N-K V CHEUNG, W L GERALD and M ESTELLER (2004). "Clustering of Gene Hypermethylation Associated With Clinical Risk Groups in Neuroblastoma." J Natl Cancer Inst 96: 1208-1219

ALIZADEH, A A, M B EISEN, R E DAVIS, C MA, I S LOSSOS, A ROSENWALD, J C BOLDRICK, H SABET, T TRAN, X YU, J I POWELL, L YANG, G E
MARTI, T MOORE, J HUDSON, JR., L LU, D B LEWIS, R TIBSHIRANI, G SHERLOCK, W C CHAN, $T$ C GREINER, D D WEISENBURGER, J O ARMITAGE, R WARNKE, R LEVY, W WILSON, M R GREVER, J C BYRD, D BOTSTEIN, P O BROWN and L M STAUDT (2000). "Distinct types of diffuse large B-cell lymphoma identified by gene expression profiling". Nature 403: 503-11

CHAN, K Y, H OZCELIK, A N CHEUNG, H Y NGAN and U S KHOO (2002). "Epigenetic factors controlling the BRCA1 and BRCA2 genes in sporadic ovarian cancer." Cancer Res 62: 4151-6

CHANG, Y T, M S WU, C J CHANG, P H HUANG, S M HSU and J T LIN (2002). "Preferential loss of Fhit expression in signet-ring cell and Krukenberg subtypes of gastric cancer." Lab Invest 82: 1201-8

CORVALÁN, A, C KORIYAMA, S AKIBA, Y EIZURU, C BACKHOUSE, M PALMA, J ARGANDOÑA and M TOKUNAGA (2001). "Epstein-Barr virus in gastric carcinoma is associated with location in the cardia and with a diffuse histology: a study in one area of Chile." Int J Cancer 94: 527-30

CREW, K D and A I NEUGUT (2006). "Epidemiology of gastric cancer." World J Gastroenterol 12: 354-62

DUNBIER, A and P GUILFORD (2001). "Hereditary diffuse gastric cancer." Adv Cancer Res 83: 55-65

EADS, C A, R V LORD, S K KURUMBOOR, K WICKRAMASINGHE, M L SKINNER, T I LONG, J H PETERS, T R DEMEESTER, K D DANENBERG, $\mathrm{P}$ $\mathrm{V}$ DANENBERG, $\mathrm{P} \mathrm{W}$ LAIRD and $\mathrm{K}$ A SKINNER (2000). "Fields of aberrant CpG island hypermethylation in Barrett's esophagus and associated adenocarcinoma." Cancer Res 60: 5021-6

ESTELLER, M (2003). "Relevance of DNA methylation in the management of cancer." Lancet Oncol 4: 351-8

FUJISHITA, T, Y DOI, M SONOSHITA, H HIAI, M OSHIMA, K HUEBNER, $\mathrm{C} M$ CROCE and $\mathrm{M} M$ TAKETO (2004). "Development of spontaneous tumours and intestinal lesions in Fhit gene knockout mice." Br J Cancer 91: 1571-4

GALlARDO, M, A SILVA, L RUBio, C ÁlVAREZ, C TORREALBA, M SALINAS, T TAPIA, P FAÚNDEZ, L PALMA, M E RICCIO, H PAREDES, M RODRÍGUEZ, A CRUZ, C ROUSSEAU, M C KING, M CAMUS, M ÁLVAREZ and P CARVALLO (2006). "Incidence of BRCA1 and BRCA2 mutations in 54 Chilean families with breast/ovarian cancer, genotypephenotype correlations." Breast Cancer Res Treat 95: 81-7

GRAZIANO, F, F ARDUINI, A RUZZO, I BEARZI, B HUMAR, H MORE, R SILVA, P MURETTO, P GUILFORD, E TESTA, D MARI, M MAGNANI and S CASCINU (2004). "Prognostic Analysis of E-Cadherin Gene Promoter Hypermethylation in Patients with Surgically Resected, Node-Positive, Diffuse Gastric Cancer 10.1158/1078-0432.CCR-03-0320."Clin Cancer Res 10: 2784-2789

HANAHAN, D and R A WEINBERG (2000). "The hallmarks of cancer." Cell 100: 57-70

HENSON, D E, C DITTUS, M YOUNES, H NGUYEN and J ALBORES-SAAVEDRA (2004). "Differential trends in the intestinal and diffuse types of gastric carcinoma in the United States, 1973-2000: increase in the signet ring cell type." Arch Pathol Lab Med 128: 765-70

HERMAN, J G and S B BAYLIN (2003). "Gene silencing in cancer in association with promoter hypermethylation." N Engl J Med 349: 2042-54

KAWAGUCHI, K, Y ODA, T SAITO, H YAMAMOTO, T TAKAHIRA, C KOBAYASHI, S TAMIYA, N TATEISHI, Y IWAMOTO and $M$ TSUNEYOSHI 
(2006). "DNA hypermethylation status of multiple genes in soft tissue sarcomas." Mod Pathol 19: 106-14

KIM, H C, J C KIM, S A ROH, C S YU, J H YOOK, S T $\mathrm{OH}, \mathrm{B}$ S KIM, K C PARK and R CHANG (2005). "Aberrant $\mathrm{CpG}$ island methylation in early-onset sporadic gastric carcinoma." J Cancer Res Clin Oncol 131: 733-40

KIM, H C, S A ROH, I H GA, J S KIM, C S YU and J C KIM (2005). "CpG island methylation as an early event during adenoma progression in carcinogenesis of sporadic colorectal cancer." J Gastroenterol Hepatol 20: $1920-6$

KIM, J, H S LEE, S I BAE, Y M LEE and W H KIM (2005). "Silencing and $\mathrm{CpG}$ island methylation of GSTP1 is rare in ordinary gastric carcinomas but common in Epstein-Barr virus-associated gastric carcinomas." Anticancer Res 25: 4013-9

KORIYAMA, C, S KITAJIMA, M NOMOTO, K SUEYOSHI, T ITOH, Y EIZURU, S YONEZAWA and $S$ AKIBA (2004). "Loss of p16/CDKN2A protein in Epstein-Barr virus-associated gastric carcinoma." Oncology 67: 81-7

KUROKI, T, F TRAPASSO, S YENDAMURI, A MATSUYAMA, $\mathrm{H}$ ALDER, $\mathrm{N} N$ WILLIAMS, L $\mathrm{R}$ KAISER and C M CROCE (2003). "Allelic loss on chromosome $3 \mathrm{p} 21.3$ and promoter hypermethylation of semaphorin 3B in non-small cell lung cancer." Cancer Res 63: 3352-5

LAUREN, P (1965). "The Two Histological Main Types of Gastric Carcinoma: Diffuse and So-Called IntestinalType Carcinoma. An Attempt at a Histo-Clinical Classification." Acta Pathol Microbiol Scand 64: 31-49

LI, Q L, K ITO, C SAKAKURA, H FUKAMACHI, K INOUE, $X$ Z CHI, $\mathrm{K}$ Y LEE, S NOMURA, C W LEE, S B HAN, H M KIM, W J KIM, H YAMAMOTO, N YAMASHITA, T YANO, T IKEDA, S ITOHARA, J INAZAWA, T ABE, A HAGIWARA, H YAMAGISHI, A OOE, A KANEDA, T SUGIMURA, T USHIJIMA, S C BAE and Y ITO (2002). "Causal relationship between the loss of RUNX3 expression and gastric cancer." Cell 109: 113-24

LIU, Z, L E WANG, L WANG, K H LU, G B MILLS, M L BONDY and Q WEI (2005). "Methylation and messenger RNA expression of p15INK4b but not p16INK4a are independent risk factors for ovarian cancer." Clin Cancer Res 11: 4968-76

MILNE, A N, R SITARZ, R CARVALHO, F CARNEIRO and G J OFFERHAUS (2007). "Early onset gastric cancer: on the road to unraveling gastric carcinogenesis." Curr Mol Med 7: 15-28

MIYAMOTO, K, K ASADA, T FUKUTOMI, E OKOCHI, Y YAGI, T HASEGAWA, T ASAHARA, T SUGIMURA and T USHIJIMA (2003). "Methylationassociated silencing of heparan sulfate D-glucosaminyl 3-O-sulfotransferase-2 (3-OST-2) in human breast, colon, lung and pancreatic cancers." Oncogene 22: 274-80

MORI, T, S R MARTÍNEZ, S J O'DAY, D L MORTON, N UMETANI, M KITAGO, A TANEMURA, S L NGUYEN, A N TRAN, H J WANG and D S HOON (2006). "Estrogen receptor-alpha methylation predicts melanoma progression." Cancer Res 66: 6692-8

NISHIDA, N, T NISHIMURA, T NAGASAKA, I IKAI, G AJAY and C R BOLAND (2007). "Extensive Methylation Is Associated with \{beta\}-Catenin Mutations in Hepatocellular Carcinoma: Evidence for Two Distinct Pathways of Human Hepatocarcinogenesis." Cancer Res 67: 4586-4594

OKA, T, M OUCHIDA, M KOYAMA, Y OGAMA, S TAKADA, Y NAKATANI, T TANAKA, T YOSHINO,
K HAYASHI, N OHARA, E KONDO, K TAKAHASHI, J TSUCHIYAMA, M TANIMOTO, K SHIMIZU and T AKAGI (2002). "Gene silencing of the tyrosine phosphatase SHP1 gene by aberrant methylation in leukemias/lymphomas." Cancer Res 62: 6390-4

PILOZZI, E, C TALERICO, A PLATT, C FIDLER and L RUCO (2003). "p73 gene mutations in gastric adenocarcinomas." Mol Pathol 56: 60-2

PISANI, P, F BRAY and D M PARKIN (2002). "Estimates of the world-wide prevalence of cancer for 25 sites in the adult population." Int J Cancer 97: 72-81

RASTOGI, T, A HILDESHEIM and R SINHA (2004). "Opportunities for cancer epidemiology in developing countries." Nat Rev Cancer 4: 909-17

RIQUELME, E, M TANG, S BÁEZ, A DÍAZ, M PRUYAS, WISTUBA, II and A CORVALÁN (2007). "Frequent epigenetic inactivation of chromosome $3 p$ candidate tumor suppressor genes in gallbladder carcinoma." Cancer Lett 250: 100-6

SARBIA, M, H GEDDERT, B KLUMP, S KIEL, E ISKENDER and $\mathrm{H}$ E GABBERT (2004). "Hypermethylation of tumor suppressor genes (p16INK4A, p14ARF and APC) in adenocarcinomas of the upper gastrointestinal tract." Int J Cancer 111: 2248

SATO, K, G TAMURA, T TSUCHIYA, Y ENDOH, K SAKATA, T MOTOYAMA, O USUBA, W KIMURA, $M$ TERASHIMA, S NISHIZUKA, T ZOU and $S \mathrm{~J}$ MELTZER (2002). "Analysis of genetic and epigenetic alterations of the PTEN gene in gastric cancer." Virchows Arch 440: 160-5

SEMBA, S, H YOKOZAKI, W YASUI and E TAHARA (1998). "Frequent microsatellite instability and loss of heterozygosity in the region including BRCA1 (17q21) in young patients with gastric cancer." Int J Oncol 12: 1245-51

TAHARA, E (2004). "Genetic pathways of two types of gastric cancer." IARC Sci Publ: 327-49

TAKAHASHI, T, N SHIVAPURKAR, E RIQUELME, H SHIGEMATSU, J REDDY, $M$ SUZUKI, K MIYAJIMA, X ZHOU, B N BEKELE, A F GAZDAR and WISTUBA, II (2004). "Aberrant promoter hypermethylation of multiple genes in gallbladder carcinoma and chronic cholecystitis." Clin Cancer Res 10: $6126-33$

TAKAHASHI, T, M SUZUKI, H SHIGEMATSU, N SHIVAPURKAR, C ECHEBIRI, M NOMURA, V STASTNY, M AUGUSTUS, C W WU, WISTUBA, II, S J MELTZER and A F GAZDAR (2005). "Aberrant methylation of Reprimo in human malignancies." Int $\mathrm{J}$ Cancer 115: 503-10

TAMURA, G (2006). "Alterations of tumor suppressor and tumor-related genes in the development and progression of gastric cancer." World J Gastroenterol 12: $192-8$

USHIJIMA, T (2007). "Epigenetic field for cancerization." J Biochem Mol Biol 40: 142-50

VAN 'T VEER, L J, H DAI, M J VAN DE VIJVER, Y D HE, A A HART, M MAO, H L PETERSE, K VAN DER KOOY, M J MARTON, A T WITTEVEEN, G J SCHREIBER, R M KERKHOVEN, C ROBERTS, P S LINSLEY, R BERNARDS and S H FRIEND (2002). "Gene expression profiling predicts clinical outcome of breast cancer." Nature 415: 530-6

VARIS, A, B VAN REES, M WETERMAN, A RISTIMAKI, J OFFERHAUS AND S KNUUTILA (2003). "DNA copy number changes in young gastric cancer patients with special reference to chromosome 19." Br J Cancer 88: 1914-9 
VAUHKONEN, M, H VAUHKONEN and P SIPPONEN (2006). "Pathology and molecular biology of gastric cancer." Best Practice \& Research Clinical Gastroenterology 20: 651-674

VIRMANI, A K, A RATHI, S ZOCHBAUER-MULLER, N SACCHI, Y FUKUYAMA, D BRYANT, A MAITRA, S HEDA, K M FONG, F THUNNISSEN, J D MINNA and A F GAZDAR (2000). "Promoter methylation and silencing of the retinoic acid receptor-beta gene in lung carcinomas." J Natl Cancer Inst 92: 1303-7

WILD, A, A RAMASWAMY, P LANGER, I CELIK, V FENDRICH, B CHALOUPKA, B SIMON and D K BARTSCH (2003). "Frequent methylation-associated silencing of the tissue inhibitor of metalloproteinase-3 gene in pancreatic endocrine tumors." J Clin Endocrinol Metab 88: 1367-73
WISTUBA, I, L MAO and A F GAZDAR (2002). "Smoking molecular damage in bronchial epithelium." Oncogene 21: 7298-306

XU, X L, J YU, H Y ZHANG, M H SUN, J GU, X DU, D R SHI, P WANG, Z H YANG and J D ZHU (2004). "Methylation profile of the promoter $\mathrm{CpG}$ islands of 31 genes that may contribute to colorectal carcinogenesis." World J Gastroenterol 10: 3441-54

YAMASHITA, K, H L PARK, M S KIM, M OSADA, Y TOKUMARU, $\mathrm{H}$ INOUE, $M$ MORI and $D$ SIDRANSKY (2006). "PGP9.5 Methylation in Diffuse type Gastric Cancer." Cancer Res 66: 3921-3927

YASUI, W, N OUE, P P AUNG, S MATSUMURA, M SHUTOH and H NAKAYAMA (2005). "Molecularpathological prognostic factors of gastric cancer: a review." Gastric Cancer 8: 86-94 